Discussion Paper No. 07-036

Local Governments in the Wake of Demographic Change:

Efficiency and Economies of Scale in German Municipalities

Benny Geys, Friedrich Heinemann, and Alexander Kalb

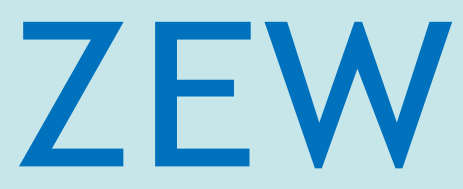

Zentrum für Europäische Wirtschaftsforschung $\mathrm{GmbH}$

Centre for European

Economic Research 
Discussion Paper No. 07-036

\section{Local Governments in the Wake of Demographic Change: Efficiency and Economies of Scale in German Municipalities}

Benny Geys, Friedrich Heinemann, and Alexander Kalb

Download this ZEW Discussion Paper from our ftp server:

ftp://ftp.zew.de/pub/zew-docs/dp/dp07036.pdf

Die Discussion Papers dienen einer möglichst schnellen Verbreitung von neueren Forschungsarbeiten des ZEW. Die Beiträge liegen in alleiniger Verantwortung der Autoren und stellen nicht notwendigerweise die Meinung des ZEW dar.

Discussion Papers are intended to make results of ZEW research promptly available to other economists in order to encourage discussion and suggestions for revisions. The authors are solely responsible for the contents which do not necessarily represent the opinion of the ZEW. 


\section{Non-technical Summary}

Since 2003 the German population has been in decline - even when immigration is taken into account. In fact, depending on the specific assumptions made concerning migration, fertility and mortality, the German population is predicted to shrink from the current 83 million inhabitants to roughly $69-74$ million in 2050 . This negative population trend is not restricted to Germany. Within the EU27, several other - mainly central and eastern European countries are expected to see their population decrease between now and 2050. Such, sometimes drastic, falls in population size are unlikely to leave public finances unaffected. Indeed, fiscal revenues are likely to be negatively affected, if only because there are simply less residents to pay taxes. Furthermore, to the extent that the population decline in most Western countries is accompanied by increased population aging, a significant strain on government budgets is probable.

In contrast to most studies focusing on the effects of demographic change in terms of population ageing and concentrating on the effects at the country, or even global level, this paper investigates the effects of demographic change in terms of population decline at the municipal level. Thereby, this analysis proceeds in two steps (using data on local governments in the state of Baden-Württemberg). Firstly, we assess German local government efficiency in the year 2001 using a stochastic parametric frontier approach. This part of the analysis builds on the idea that one can expect more efficient governments to be better able to adequately address adverse economic, fiscal or demographic shocks. The overall level of efficiency of German local governments as well as the degree of heterogeneity therein across municipalities thus provides an indication of the likely strain of future demographic decline on municipal operations - and which municipalities might suffer harder from these adverse demographic shocks.

Secondly, we study the properties of the German municipalities' cost functions with respect to the impact of population size (i.e. 'scale elasticities'). Given that German communities generally have to expect substantial losses of population in the coming decades, it is important to know whether the cost of producing public goods is likely to decline at the same, slower or faster pace. In the case of slower cost decline, significant strain on local public budgets is to be expected. Importantly, by regarding the elasticity of costs to population size for various clusters of municipalities (with divisions based on population size), we are able to gather 
some indication of which type of municipalities (i.e. large, median or small) is most sensitive to population changes.

The results show that, on average, municipalities in Baden-Württemberg produce their output with costs approximately $12 \%$ to $14 \%$ higher than the most efficient municipalities in the sample. While this, as mentioned, leaves some leeway for improvements in efficiency without resorting to politically costly tax increases, it suggests that future population decline might put severe strain on some local governments. Secondly, we show that smaller municipalities with up to about 10.000 inhabitants exhibit larger unexploited economies of scale. That is, the costs for providing public goods generally rise (fall) underproportionally with population size, but this effect is stronger for smaller municipalities. This suggests that smaller municipalities will be especially hard hit by the population losses forecasted for most German municipalities since costs will tend to fall at a slower pace than population. Taken together, our results provide a case for boundary reviews or increased inter-communal cooperation in the provision of (certain) public goods. 


\title{
Local Governments in the Wake of Demographic Change: Efficiency and Economies of Scale in German Municipalities
}

\author{
Benny Geys ${ }^{\mathrm{a}}$, Friedrich Heinemann ${ }^{\mathrm{b}}$, Alexander Kalb ${ }^{\mathrm{b}}$ \\ a Wissenschaftszentrum Berlin für Sozialforschung (WZB), "Market Processes and Governance" \\ Research Unit, Reichpietschufer 50, D-10785 Berlin, Germany; e-mail: geys@wzb.eu \\ ${ }^{\mathrm{b}}$ Zentrum für Europäische Wirtschaftsforschung (ZEW), "Corporate Taxation and Public Finance" \\ Research Unit, L 7, 1, D-68161 Mannheim, Germany; e-mail: heinemann@zew.de; kalb@zew.de
}

June 2007

\begin{abstract}
German municipalities are expected to suffer from (often significant) population losses in the upcoming decades. We assess these local governments' vulnerability to the fiscal consequences of this demographic decline through two means (using a sample of 1021 municipalities in the state of Baden-Württemberg). First, we consider local government cost efficiency. This indicates that there is a substantial divergence in efficiency despite a homogeneous institutional setting, leaving at least some - mainly smaller - municipalities vulnerable to adverse demographic/financial shocks. Secondly, we estimate the elasticity of local government cost functions to population size. We find that costs rise (fall) underproportionally with population size for small municipalities, whereas this is less the case for larger municipalities. This implies that especially small municipalities are vulnerable to increasing cost pressures under declining population. The overall implication is that large German municipalities (over 10.000 inhabitants) will more easily be able to cope with the expected population decline than smaller ones, supporting a case for boundary reviews or more extensive inter-communal cooperation.
\end{abstract}

Keywords: Demographic change; Efficiency; Local government performance; Stochastic frontier analysis; Economies of scale; Cost elasticity; German municipalities.

JEL-codes: D61, H40

We would like to thank Sebastian Hauptmeier for helpful comments. Support by the "Förderkreis Wissenschaft und Praxis at the Centre for European Economic Research" is gratefully acknowledged.

\footnotetext{
Address of correspondence: Alexander Kalb, Zentrum für Europäische Wirtschaftsforschung (ZEW), "Corporate Taxation and Public Finance" Research Unit, L 7, 1, D-68161 Mannheim, Germany; e-mail: kalb@zew.de; Tel: +49 (0)621/1235-282; Fax: +49 (0)621/1235-223.
} 


\section{Introduction}

Even when immigration is taken into account, the German population has been in decline since 2003 (Federal Statistical Office Germany, 2006a). Moreover, this trend is expected to continue in the upcoming decades. In fact, depending on the specific assumptions made concerning migration, fertility and mortality, the German population is predicted to tumble from the current 83 million inhabitants to roughly 69-74 million in 2050 (Federal Statistical Office Germany, 2006b). This negative population trend is not restricted to Germany. Within the EU27, several other - mainly central and eastern European - countries are expected to see their population decrease between now and 2050. Regarding the period between 2025 and 2050, the situation is even more general. Indeed, in that time period, all but 8 countries in the EU27 (i.e. Belgium, France, Ireland, Cyprus, Luxemburg, Malta, Sweden and UK) are expected to witness population reductions (Eurostat, 2006).

Such, sometimes drastic, falls in population size are unlikely to leave public finances unaffected. Indeed, fiscal revenues are likely to be negatively affected (if only because there are simply less residents to pay taxes). Furthermore, to the extent that the population decline in most Western countries is accompanied by increased population aging (putting upward pressure on public expenditures), a significant strain on government budgets is probable. In line with this, "many Europeans view population decline and aging as threats to national influence and the welfare state" (Van de Kaa, 1987, 1).

Interestingly, most studies thus far focus on the effects of demographic change in terms of population aging rather than population decline (e.g. Jackson and Felmingham, 2002; Bloom and Canning, 2004; Seitz et al., 2007). Moreover, the majority of studies on demographic change concentrate on the effects at the country - or even global - level (e.g. Bloom and Canning, 2004; Batini et al., 2006). However, as mentioned above, demographic change is not limited to changes in the age distribution (e.g. increasing the share of individuals over 65), but can also refer to variations in population size. Furthermore, the effects of demographic change (whether in terms of aging or decline) are unlikely to be constrained to the national level. Indeed, regional and local governments are also susceptible to its implications since "the lived experience of population ageing [and decline] will be played out at the level of local rather than national government" (Jackson, 2004, 101). Hence, an exclusive focus on the national level is unwarranted and, moreover, fails to notice possible differences across regions within a 
country (cf. Jackson and Felmingham, 2002). In the present paper, we take a first step to address both these elements. That is, we concentrate on a) the local level of government and b) population decline rather than aging. While the policy relevance of such research is evident, it has to date received only limited attention. In fact, to the best of our knowledge, only one study has thus far attempted to assess the impact of population decline on local government operations (Felmingham et al., 2002).

Our analysis proceeds in two steps (using data on 1021 municipalities in the state of BadenWürttenberg). Firstly, we assess German local government efficiency in the year 2001 using a stochastic parametric frontier approach. This part of the analysis builds on the idea that one can expect more efficient governments to be better able to adequately address adverse economic, fiscal or demographic shocks. Still, currently inefficient governments may have some leeway to address such problems (simply by improving their performance). The overall level of efficiency of German local governments as well as the degree of heterogeneity therein across municipalities thus provides an indication of the likely strain of future demographic decline on municipal operations - and which municipalities might suffer harder from these adverse demographic shocks. While we are not the first to analyze local government efficiency (e.g., Hayes and Chang, 1990; De Borger et al., 1994; De Borger and Kerstens, 1996; Kalseth and Ratts $\varnothing, 1998$; Athanassopoulos and Triantis, 1998; Worthington, 2000; Sampaio De Sousa and Stosic, 2005; Hindriks and Gerard, 2005; Geys, 2006; Balaguer-Coll et al., 2007; Borge et al., 2007; Geys and Moesen, 2007a, b; for an excellent review, see De Borger and Kerstens, 2000), this is, to the best of our knowledge, the first study that attempts to provide such an assessment for German local governments.

Secondly, we study the properties of the German municipalities' cost functions with respect to the impact of population size (i.e. 'scale elasticities'). Given that German communities generally have to expect substantial losses of population in the coming decades, it is important to know whether the cost of producing public goods is likely to decline at the same, slower or faster pace. In the case of slower cost decline, significant strain on local public budgets is to be expected. Importantly, by regarding the elasticity of costs to population size for various clusters of municipalities (with divisions based on population size), we are able to gather some indication of which type of municipalities (i.e. large, median or small) is most sensitive to population changes. 
The results show that, on average, municipalities in Baden-Württemberg produce their output with costs approximately $12 \%$ to $14 \%$ higher than the most efficient municipalities in the sample. While this, as mentioned, leaves some leeway for improvements in efficiency without resorting to politically costly tax increases, it suggests that future population decline might put severe strain on some local governments. Secondly, we show that smaller municipalities (up to about 10.000 inhabitants) exhibit larger unexploited economies of scale. That is, the costs for providing public goods generally rise (fall) underproportionally with population size, but this effect is stronger for smaller municipalities. This suggests that smaller municipalities will be especially hard hit by the population losses forecasted for most German municipalities (since costs will tend to fall at a slower pace than population). Taken together, our results provide a case for boundary reviews or increased inter-communal cooperation in the provision of (certain) public goods.

The remainder of the paper is structured as follows. Section 2 introduces the institutional setting of the German local governments and thereby clarifies the context of local public decision-making. Section 3 introduces the concept and measurement of government efficiency and presents the results from an assessment of the German municipalities in the year 2001. In Section 4, 'scale efficiencies' in the provision of public goods for the German municipalities are analyzed. Conclusions are drawn in section 5.

\section{German local institutional setting}

Baden-Württemberg consists of 1111 municipalities ranging in size from 98 inhabitants in the smallest municipality (Böllen) to almost 600,000 inhabitants in the largest one (Stuttgart). The institutional setting is the same in all these municipalities (such that our analysis will be unaffected by the institutional design of government). That is, municipal political institutions consist on the one hand of the local council, which is elected every five years and is the main decision-making body of the municipalities. On the other hand, there is a directly elected major (eight-year terms), who acts as chairman of the municipal council. Both institutions have their own statutory responsibilities, although the major has significant agenda-setting powers. ${ }^{1}$

\footnotetext{
We should note here that, contrary to the state or federal level, the formation of governing majorities within
} the local council is not institutionalized in the local law of Baden-Württemberg. Nonetheless, their existence 
Though the municipalities constitute the lowest level of government in Germany, they still retain considerable autonomy in raising revenue and assume significant responsibilities at the expenditure side. Looking first at the revenue structure of German local governments, we find that they have three main income sources: tax revenue (45\% of current revenues ${ }^{2}$ in 2001), allocation of funds (from the federal and state level, from municipal equalization schemes, and so on; $26 \%$ of current revenues) and revenue from user charges ( $8 \%$ of current revenues) (see figure $\left.1(1)^{3}\right)$. With respect to tax revenues, local governments can independently decide on five types of taxes: trade tax ("Gewerbesteuer"), property tax ("Grundsteuer"), tax on keeping dogs, second residence tax and entertainment tax. While revenues from the trade and property tax constitute the bulk of local governments' tax revenues (42\% and $13 \%$ of total tax revenue in 2001 respectively, see figure 1(2)), revenues from the other three types of taxation are generally minimal (and the last two types of taxes are not raised by all municipalities). Besides these own tax revenues, the municipalities receive a share of the revenue accruing from the federal income tax (15\% of revenue raised in Baden-Württemberg), the interest income tax (12\% of revenue generated in Baden-Württemberg) and the value added tax (2.2\% of the VAT-revenue raised in Germany as a whole). As shown in figure 1(2), these revenues constitute a considerable share of local government tax revenues (i.e. $40 \%$ and $4 \%$ respectively).

is uncontested. These inter-party cooperations are used to facilitate and, to a certain extent, control the formation of opinions and decision-making.

2 We focus on current rather than total revenue, thereby excluding revenue from the capital account. The reason is that revenues on the capital account are much more volatile and would give a biased view of revenues at a given point in time.

3 Other sources of revenue include administrative revenue, income from interest, shares in profits, concession levy, support for debt service and cost-accounting depreciation. 
Figure 1: Structure of the current revenue (1) and composition of tax revenue (2) for all municipalities in Baden-Württemberg in 2001
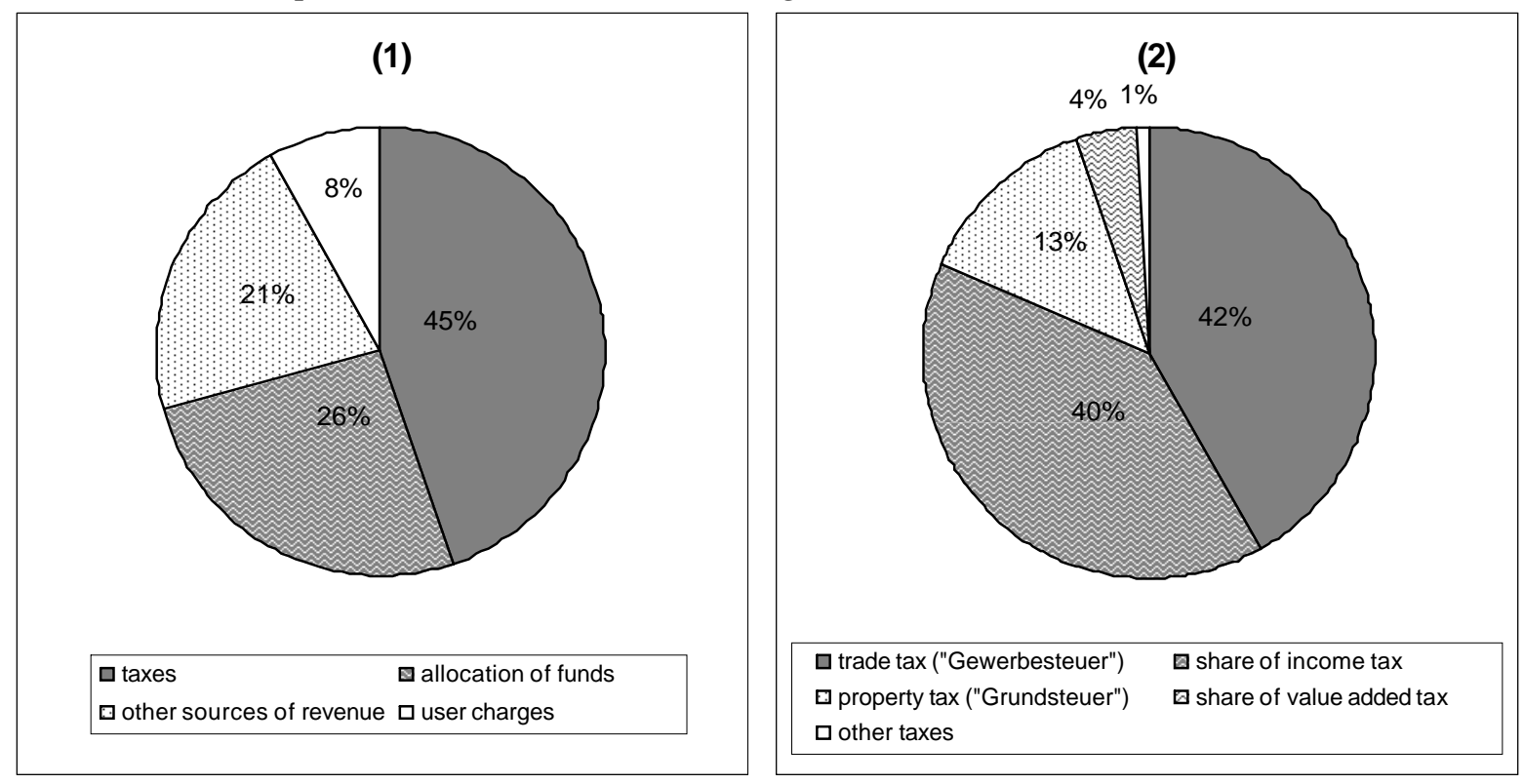

Source: Statistical office of Baden-Württemberg and own calculations

Turning to the expenditure side, the revenue obtained by local governments in BadenWürttemberg serves to finance three types of tasks. ${ }^{4}$ Firstly, local governments face voluntary tasks. The municipalities are not obliged to perform these tasks but they can assume responsibility for them if they so desire. Examples are cultural affairs (e.g. library, museum, theatre), social affairs (e.g. residential home for the elderly, welfare centre), sport facilities (e.g. public swimming pools, sports fields), entertainment facilities (e.g. hiking trails), traffic facilities (e.g. tram, harbour), partnership with foreign municipalities and municipal business development. The second type of tasks can be labelled as duties without instruction. These have to be performed by the municipalities, but do not involve detailed prescriptions imposed by a higher-level government concerning how local governments should perform these tasks. Examples from tasks in this category are the lighting and cleaning of public roads, the creation, support and expansion of graveyards, the construction of (municipal) roads, children playgrounds, the fire department, waste disposal and so on. Finally, there are duties with instruction. Local governments are obliged to perform the tasks, and the state imposes detailed regulations on how municipalities should perform them. Therefore, the implementation of these tasks is predetermined by the state. An example would be the running of local police authorities.

4 A more detailed classification and description of these tasks is given in Gern (2005). 


\section{German local government efficiency}

Efficiency in the production of public services is one degree of freedom in local communities' policy agenda to counteract the fiscal pressure arising from population ageing and decline. Hence, the measurement of efficiency in local public good production is a logical first empirical step to assess the impact of these demographic changes on local public finances. It serves, moreover, a double function. First, it lays the methodological basis to study the link between population size and cost pressure in section 4. Second, it allows a first look at the extent to which municipalities might be able to respond to adverse economic, fiscal or demographic shocks. Low efficiency scores for municipalities today should therefore not be (exclusively) interpreted as leeway for cost savings tomorrow once population shrinkage occurs. This would effectively be rather naive. On the contrary, current inefficiencies are more likely to hint towards poor (historical) performance in terms of adjusting service production to a changing environment and an inability to provide public services in the least costly way. Public entities that are currently inefficient may therefore be expected to be particularly severely hit by the changing size and structure of their population.

\subsection{Efficiency estimation: empirical approaches ${ }^{5}$}

Determining the efficiency of a given number of decision-making units firstly requires the selection of a set of input-output combinations that designate efficient behaviour (i.e. those combinations where the inputs are most productively used). Then, in a second step, one can designate deviations from this 'best practice frontier' as inefficiency. Both these steps have been addressed in a number of different ways in the literature (for an introduction, see Lovell, 1993). Specifically, the best practice frontier can be generated either parametrically or nonparametrically. In non-parametric approaches such as Data Envelopment Analysis (DEA; Farrell, 1957) or Free Disposal Hull (FDH; De Prins et al., 1984), the frontier is generated as a piecewise linear envelopment of the data. Parametric approaches, on the other hand, determine the best practice frontier on the basis of a specific functional form using advanced econometric techniques. In evaluating deviations from this best practice frontier, early studies interpreted any deviation as inefficiency (a deterministic approach). This, however, is problematic since observed levels of inputs and outputs in real-world applications may be subject to measurement errors or other stochastic influences. In addition, even communities

\footnotetext{
$5 \quad$ For more details, see Geys and Moesen (2007a).
} 
with an identical institutional setting may differ substantially in natural (e.g. geographical) or socio-economic (e.g. extent of unemployment etc.) restrictions on public service provision, which may even further distort the picture. To the extent that this is the case, one should attempt to differentiate between these 'errors' and inefficiency (using a stochastic approach).

We build on the stochastic, parametric approach to efficiency measurement developed by Aigner et al. (1977) and Meeusen and van den Broeck (1977). Employing a translogarithmic specification (cf. Christensen et al., 1973), a parametric frontier model can be written as (dropping subscripts for decision-making units for convenience):

$$
\ln \mathrm{C}=\alpha+\sum_{r=1}^{s} \beta_{r} \ln y_{r}+1 / 2 \sum_{r=1}^{s} \sum_{q=1}^{s} \lambda_{r q} \ln y_{r} \ln y_{q}+\underbrace{v+u}_{=\varepsilon}
$$

where $\mathrm{C}$ designates the input indicator (which in effect can be interpreted as the money equivalent of multiple inputs), $y$ indicates the various output indicators, $s$ points to the number of outputs incorporated in the model and $\beta_{\mathrm{r}}$ and $\lambda_{\mathrm{rq}}$ are parameters to be estimated. ${ }^{6}$ The crucial difference with the non-parametric deterministic approaches mentioned above is that this parametric method allows one to distinguish between the effects of measurement error and inefficiency. This is achieved by introducing a composed error term consisting of a symmetric component $(v)$ (generally assumed to be white noise) and a one-sided non-negative component $(u \geq 0)$ representing inefficiency. The latter component is mostly assumed to follow a half-normal or a truncated normal distribution (cf. De Borger and Kerstens, 1996; Méon and Weill, 2005). Both error components are assumed to be independent. While estimation of equation (1) provides values for the composed error term $(\mathrm{v}+\mathrm{u})$, Jondrow et al. (1982) and Bauer (1983) show that, for any organisation $i$, the conditional distribution of $u_{i}$ given $\left(v_{i}+u_{i}\right)$ contains all available information about $u_{i}$. As a consequence, this information can be used to generate point estimates for the inefficiency component of any given decisionmaking unit i. One can thereby either build on the mean or the mode of this conditional distribution (see Jondrow et al., 1982; Bauer, 1983), though both generally lead to comparable results in empirical applications (hence, we will only report the results based on the mean of

6 The translogarithmic function in equation (1) extends the more basic Cobb-Douglas type cost or production function. Specifically, in a Cobb-Douglas function, the third term on the right hand side of equation (1) is absent: i.e. only the (logged) levels of the outputs are included and not the squared values, nor the crossproduct terms. Obviously, the use of Cobb-Douglas versus translogarithmic functional form can be tested by assessing whether the coefficients $\lambda_{\text {rq }}$ are jointly significantly different from 0 (see below). 
the conditional distribution in section 3.2). These point estimates indicate to what extent inputs can be reduced without reducing current output levels. ${ }^{7}$

Two possible problems should be mentioned. Firstly, cost function based approaches along the lines of equation (1) could be challenging due to heterogeneity of factor costs across the jurisdictions under scrutiny. Fortunately, factor price divergence is not substantially affecting our application since the costs of labour and capital are identical for the municipalities of Baden-Württemberg (i.e. they face the same interest rates and wages). Interest rate homogeneity is given by the fact that a) all municipalities have access to the same capital market and b) the federal government guarantees the absence of differences in risk premiums for all German jurisdictions. Identical wages are guaranteed via a uniform collective labour agreement.

Secondly, the efficiency estimates as derived from equation (1) treat all municipalities on the same footing. However, exogenous (or non-discretionary) influences may shape local government performance (Battese and Coelli, 1995; Stevens, 2004). Indeed, certain characteristics of a municipality may affect how successful the local government is in carrying out its tasks, even though it cannot affect these elements in the short (or even long) run. Examples of such external forces are the geographic characteristics of the area or the socio-economic make-up or density of the population. A municipality in a hilly region is likely to spend more money on a given level of road infrastructure, but should therefore not necessarily be deemed less efficient in carrying out this task. Disregarding the effect of such background factors can thus lead to an overestimation of government inefficiency. We address this issue by assuming that the inefficiency term $(\mathrm{u})$ in the error of equation (1) is a function of a set of background variables (cf. Battese and Coelli, 1995). In other words, and as discussed in Coelli (1996), $\mathrm{u}$ is "assumed to be independently distributed as truncations at zero of the $N\left(m_{i t}, \sigma_{u}^{2}\right)$ distribution where $m_{i t}=\delta z_{i t}$ " (p. 7). In this extension, $z_{i t}$ is a vector of background variables (for municipality $i$ and time period $t$ ) which are expected to influence (in)efficiency and $\delta$ is a vector of parameters to be estimated. Technically, this corrects the derived efficiency measures for the existence of non-discretionary factors and leads to the following modified model:

Building the best practice frontier based on the decision-making units at hand by definition implies that the ensuing efficiency measures are relative rather than absolute measures - and only have meaning within the specific sample employed. This clearly holds for all the procedures brought forward, and should be kept in mind in empirical applications. 


$$
\begin{aligned}
& \ln \mathrm{C}=\alpha+\sum_{r=1}^{s} \beta_{r} \ln y_{r}+1 / 2 \sum_{r=1}^{s} \sum_{q=1}^{s} \lambda_{r q} \ln y_{r} \ln y_{q}+v+u \\
& u=\gamma+\sum_{i=1}^{I} \delta_{i} z_{i}+w
\end{aligned}
$$

where the error term of equation (3), w, is defined by the truncation of the normal distribution with zero mean and variance $\sigma^{2}$ (Battese and Coelli, 1995). The latter assumption assures that the inefficiency component $u$ can only take values bigger than or equal to zero. ${ }^{8}$

\subsection{Efficiency estimation: an application to German local governments}

As mentioned, we employ a stochastic parametric reference technology to determine the level of (in)efficiency of 1021 of the 1111 municipalities in the state of Baden-Württemberg in the year 2001 (data availability precluding the inclusion of the remaining municipalities). To determine which input, output and background variables to include in the analysis, we rely on previous literature studying local government efficiency (e.g. Vanden Eeckaut et al., 1993; De Borger et al., 1994; De Borger and Kerstens, 1996; Geys and Moesen, 2007a, b). Following this 'common standard' has the advantage that our results are to some extent comparable with these studies. As our prime input variable $(\mathrm{C})$, we employ total current primary expenditures in the municipality in 2001. This includes all spending on the current budget except interest and amortization repayments from local public debts. ${ }^{9}$ Spending from the capital budget is ignored as decisions to invest in large infrastructure projects are infrequent events and thus tend to inflate spending in the year they occur. Given the cross-sectional nature of our analysis, focus on the current budget avoids distortions resulting from fluctuating investments.

To measure the level of local public good provision, we include six output variables that relate to important responsibilities of the German local governments with respect to social, educational, recreational and infrastructure services: (a) the number of students in local public schools ("Grund- and Hauptschulen"), (b) the number of kindergarten places, ${ }^{10}$ (c) the surface

8 A complete coverage of all relevant y and $z_{i}$ would be necessary to derive the real extent of inefficiency and the possible cost cuts given the municipality's output. As data limitations are likely to make this unattainable, we must be cautious to equate observed 'inefficiencies' with realizable cost savings. Nevertheless, even with an incomplete coverage, $u$ offers valuable insights in the municipalities' 'value for money'. These subtleties should, however, be kept in mind if we speak about inefficiencies in the following empirical analysis.

9 Including these debt service costs does not affect the results in any significant manner (available upon request).

10 Only the total number of public and private kindergarten places of the year 2002 was available. While it would be preferred to use only the number of public kindergarten places, the addition of private 
of public recreational facilities, (d) the total population ${ }^{11}$, (e) the population over age 65 , and (f) the number of employees paying social security contributions.

Finally, we include two sets of background variables in the model: socio-economic and political. The socio-economic background variables include population density (inhabitants per are) and the number of unemployed in relation to total population. Population density proxies the rural/urban divide and is included under the argument that it can influence the ability of the authority to concentrate provision of the local public services (Stevens, 2005). Furthermore, it proxies the heterogeneity of property prices, which tend to differ substantially between rural and urban municipalities (and may thereby affect the cost situation of municipalities). While high population density might entail cost advantages due to regional concentration of services, higher property costs in urban areas (and other problems of agglomeration) may render production more costly. The overall effect on efficiency is therefore ambiguous. A similar ambiguity emerges for the unemployment rate since it implies a) higher spending on unemployment and housing benefits (a 'cost effect') and b) lower demand for high-cost (or high-quality) public services (demand for which is likely to increase with income levels) (a 'preference effect'). As a political background variable, we include the Herfindahl index to measure political concentration or monopolization in the local council. It is calculated using seat shares of the main national parties (CDU, FDP, SPD, GRÜNE) and of the so-called 'free voter unions' ${ }^{12}$ High concentration (or low fragmentation) represents low political competition and should therefore reduce efficiency (cf. Ashworth et al., 2006). ${ }^{13}$

The results - obtained using FRONTIER 4.1 (developed by Coelli, 1996) - are summarized in Table 1. Specifically, we estimate three related models. The first disregards the effect of background variables and could be seen as a 'baseline' model (presented in columns (1) and (4)). In the second model, we include the socio-economic background variables (unemployment and population density) (columns (2) and (5)) while in the third model we also incorporate the Herfindahl index (columns (3) and (6)). In each case, we estimate both a

kindergartens may not be overly problematic. The reason is that these places also imply an 'organisational' burden for the local government.

11 Population is a key variable in the context of demographic change and expected population losses. Indeed, a population coefficient in the cost function significantly below one would hint to increasing economies of (population) scale and, hence, towards the threat of increasing cost pressure with a declining number of inhabitants. We return to this more extensively in section 4.

12 'Free voter unions' are loose federations of persons not belonging to specific political parties and exist only at the local level.

13 The summary statistics of the input, output and environmental variables can be found in table A2 of appendix A. 
Cobb-Douglas (columns (1), (2), (3)) and translogarithmic cost function (columns (4), (5), (6)). By definition, the municipalities lying on the best practice frontier reach efficiency scores of one, the other, less efficient exhibit efficiency scores that are bigger than one. Full results of all these estimations are provided in table A1 of appendix A.

Table 1: Summary statistics on the cost efficiency of the local governments in Baden Württemberg in $2001(N=1021)$

\begin{tabular}{|l|ccc|ccc|}
\hline & \multicolumn{3}{|c|}{ Cobb-Douglas } & \multicolumn{3}{c|}{ Translog } \\
\hline & $\begin{array}{c}\text { No control } \\
\text { variables } \\
(1)\end{array}$ & $\begin{array}{c}\text { Socio- } \\
\text { economic } \\
\text { controls (2) }\end{array}$ & $\begin{array}{c}\text { All control } \\
\text { variables } \\
(3)\end{array}$ & $\begin{array}{c}\text { No control } \\
\text { variables } \\
(4)\end{array}$ & $\begin{array}{c}\text { Socio- } \\
\text { economic } \\
\text { controls (5) }\end{array}$ & $\begin{array}{c}\text { All control } \\
\text { variables } \\
(6)\end{array}$ \\
\hline Average & 1.229 & 1.138 & 1.141 & 1.202 & 1.120 & 1.122 \\
Standard deviation & 0.203 & 0.176 & 0.179 & 0.159 & 0.134 & 0.136 \\
Minimum & 1 & 1 & 1 & 1 & 1 & 1 \\
Maximum & 4.355 & 4.566 & 4.499 & 3.500 & 3.708 & 3.666 \\
Number efficient & 1 & 1 & 1 & 1 & 1 & 1 \\
\hline
\end{tabular}

As can be seen from table 1, disregarding background variables (columns (1) and (4)), local governments in Baden-Württemberg are characterized by cost levels which are approximately $20 \%$ to $23 \%$ above the efficient frontier. When we include political and socio-economic background variables into the estimation, inefficiency is reduced (as expected). Still, costs remain roughly $12 \%$ to $14 \%$ above the efficient level (column (3) and (6)). Although, as explained above, we should be cautious to equate these inefficiencies with potential cost cuts, it should be kept in mind that the frontier generated by the sample of municipalities will by construction be at least as high as the 'true' frontier. This implies that the efficiency ratings provided in table 1 are best regarded as a lower limit of 'true' inefficiency.

Important with respect to our main research question - viz the expected effect of predicted demographic decline - it is clear that the Baden-Württemberg local governments show a substantial heterogeneity with regard to their 'value for money' (as represented by the standard deviation in inefficiency scores). The variation in efficiency ratings is also represented in figure 2. This histogram shows the number of municipalities (on the Y-axis) with a given level of inefficiency (on the $\mathrm{X}$-axis), using results from the translogarithmic specifications. Light-grey cubes are inefficiency scores without control variables, black cubes represent inefficiency scores when controlling for socio-economic background variable and dark-grey cubes depict inefficiency scores when including all control variables. 
Figure 2: Baden-Württemberg local governments' cost inefficiency in $2001(N=1021)$

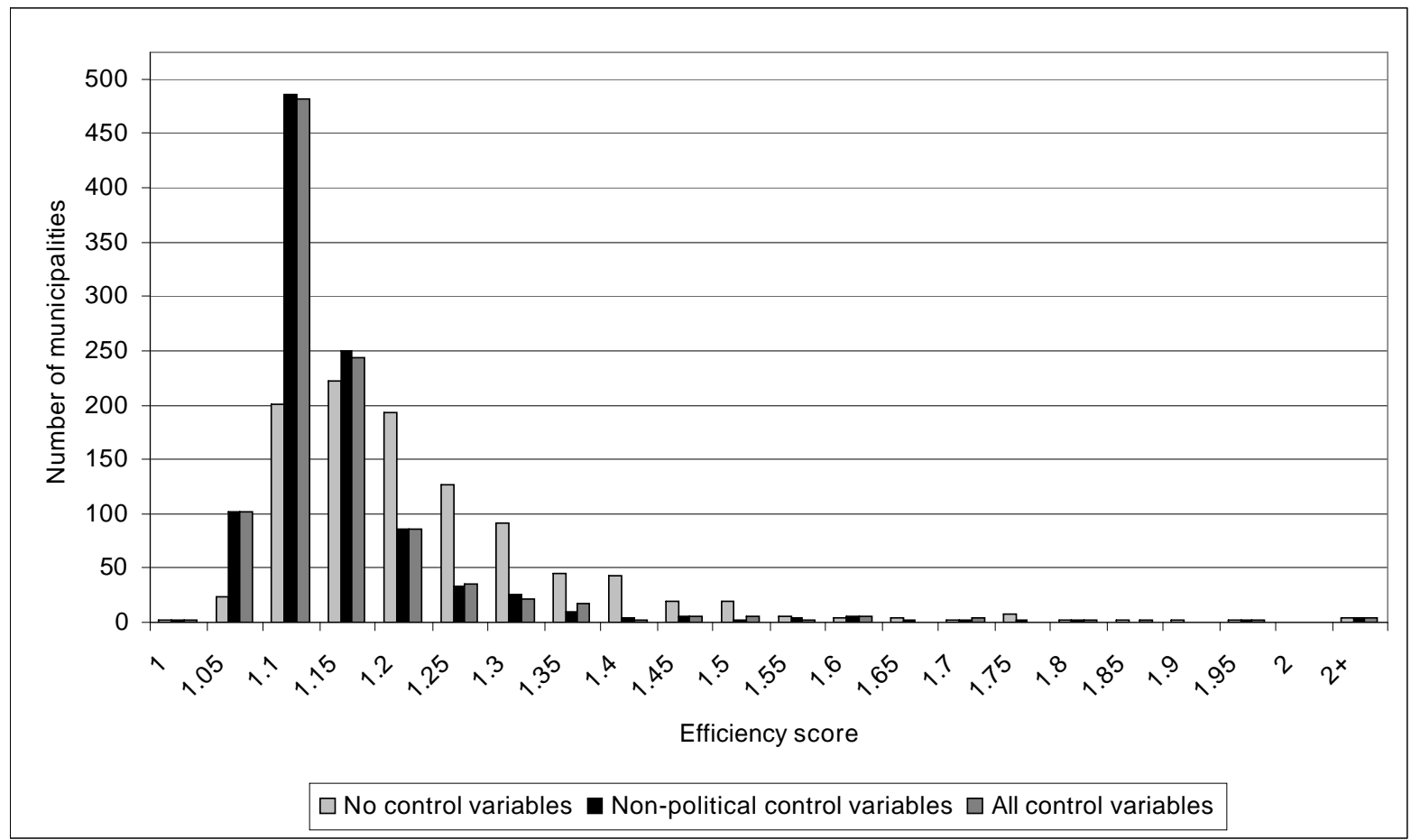

Note: Results based on translogarithmic cost function.

It is clear from figure 2 that the distribution of inefficiency has a large right-hand tail. Most municipalities have a limited degree of inefficiency, though some are deemed to be very inefficient. This suggests that at least some municipalities have only limited flexibility in addressing adverse economic, fiscal or demographic shocks and are likely to suffer quite strongly under the generally expected demographic decline. Although a more positive reading of our results might suggest that currently inefficient municipalities have some leeway for improvements in efficiency without resorting to politically costly tax increases, it remains doubtful that such municipalities are able to increase their efficiency under adverse conditions. To the extent that municipalities remain equally (in)efficient in the future, public finances are likely to become more severely constrained in inefficient municipalities when their population (and thereby a main source of (tax) revenue) declines. Not shown in the figure is that mainly the smaller municipalities (especially those under 3000 inhabitants) are found to be relatively inefficient while municipalities between approximately 6000 and 9000 inhabitants are deemed most efficient (details available upon request).

Before we conclude this section, it may be of interest to point to the findings of the nondiscretionary variables included in the model. These results, provided in table A1 of appendix $\mathrm{A}$, indicate that the unemployment rate does not robustly affect inefficiency. Hence, no clear statement of the effect of unemployment on the (technical) efficiency in the municipalities of 
Baden-Württemberg can be made. Population density, on the other hand, significantly increases measured inefficiency in all specifications. This indicates that cost disadvantages resulting from, say, higher property prices outweigh agglomeration advantages. This result may also reflect the fact that large cities tend to have central place functions, such as the arts and culture (cf. Heilbrun, 1992), which significantly affects their cost structure. Finally, as expected, political concentration (proxied by the Herfindahl index) significantly reduces efficiency. This indicates that high levels of political competition are associated with high efficiency - a result in line with our theoretical expectations (see also Ashworth et al., 2006).

\section{Economies of scale}

The previous section indicated that there are significant differences in the level of (in)efficiency of local governments in Baden-Württemberg. This suggests that the population decline expected in Germany over the upcoming decades is likely to cause a severe strain on some of these municipalities (especially if they should fail to increase their efficiency). In the current section, we expound on these findings and take a closer look at economies of scale in the provision of public goods by Baden-Württemberg' municipal governments. Such an analysis can deliver important insights into how costs behave when the number of inhabitants starts to decline (as expected for most German regions; see Federal Statistical Office Germany, 2006b). Indeed, pressure on local public finances is likely to be more severe when costs change underproportionally to population changes, compared to the case where significant economies of scale are absent (since costs and population will then move in roughly comparable measure).

A key variable for the identification of economies of scale in our setting is the coefficient for the population variable in the cost functions estimated in section 3. Since all output variables as well as the dependent variable in these estimations are in natural logs, this coefficient can be interpreted as a cost elasticity (with respect to population). Therefore, it shows how a one percentage increase/decrease of population affects the costs for providing a bundle of public goods. An elasticity significantly below one indicates increasing economies of scale and thereby suggests that the costs of providing public goods for one additional inhabitant rise underproportionally. Focusing on the Cobb-Douglas specification (columns (1)-(3) in table A1), the coefficients for population are all highly statistically significant and range from 0.63 
to 0.68. Hence, municipalities in Baden-Württenberg operate on average under increasing economies of scale. That is, cost per capita can be cut when the average scale of production where larger (either through merging municipalities or inter-municipal co-operating on the provision of public goods).

Importantly, one might wonder whether these economies of scale play a different role in small versus large municipalities. To the extent that this is the case, population decline affects small and large municipalities differently. To answer this question, we estimate Cobb-Douglas cost functions for five different classes of population size in a so-called "rolling regression" and investigate how the estimated cost elasticity (with respect to population) changes. Table 2 shows the five different size classes for which we carry out these regressions. As can be seen, we establish two classes for "small" municipalities, two classes for medium-sized municipalities and one class for large municipalities. ${ }^{14}$ The division of these classes was inspired by the requirement to include a number of municipalities in each class high enough to carry out a reasonable regression. Note also that, as before, we run regressions disregarding the control variables, including only the socio-economic background variables and including all controls. There is partial overlap between the various groups to get a more continuous view of the effect of population size across the various groups.

Table 2: Classes of population size for the "rolling regression"

\begin{tabular}{|c|c|c|c|c|c|}
\hline & \multicolumn{5}{|c|}{ Class size (number of inhabitants in thousands) } \\
\hline & $0-3$ & $2-4$ & $3-6$ & $5-10$ & $10-100$ \\
\hline & \multicolumn{2}{|c|}{ "small" } & \multicolumn{2}{|c|}{ "medium-sized" } & "large" \\
\hline $\begin{array}{l}\text { Number of municipalities } \\
\text { in each class }\end{array}$ & 271 & 284 & 328 & 268 & 242 \\
\hline $\begin{array}{l}\text { In \% of all considered } \\
\text { municipalities }(\mathrm{N}=1012)\end{array}$ & 26.78 & 28.06 & 32.41 & 26.48 & 23.91 \\
\hline
\end{tabular}

The results of the rolling regression are graphically represented in figure 3 . This figure shows for every size class (X-axis) the corresponding estimated cost elasticity; that is, the estimated coefficient for the output variable 'total population' (Y-axis). The light-grey line depicts the development of the cost elasticity when no control variables are included, the black (dark-

14 We excluded municipalities with more than 100.000 inhabitants as such metropolitan areas (e.g. Stuttgart or Mannheim with roughly 590.000 and 309.000 inhabitants respectively) may distort the results. After this correction, we are left with a total of 1012 municipalities for the analysis. 
grey) line displays the development when controlling for socio-economic (and political) nondiscretionary variables.

Figure 3: Development of cost elasticities with increasing size of population

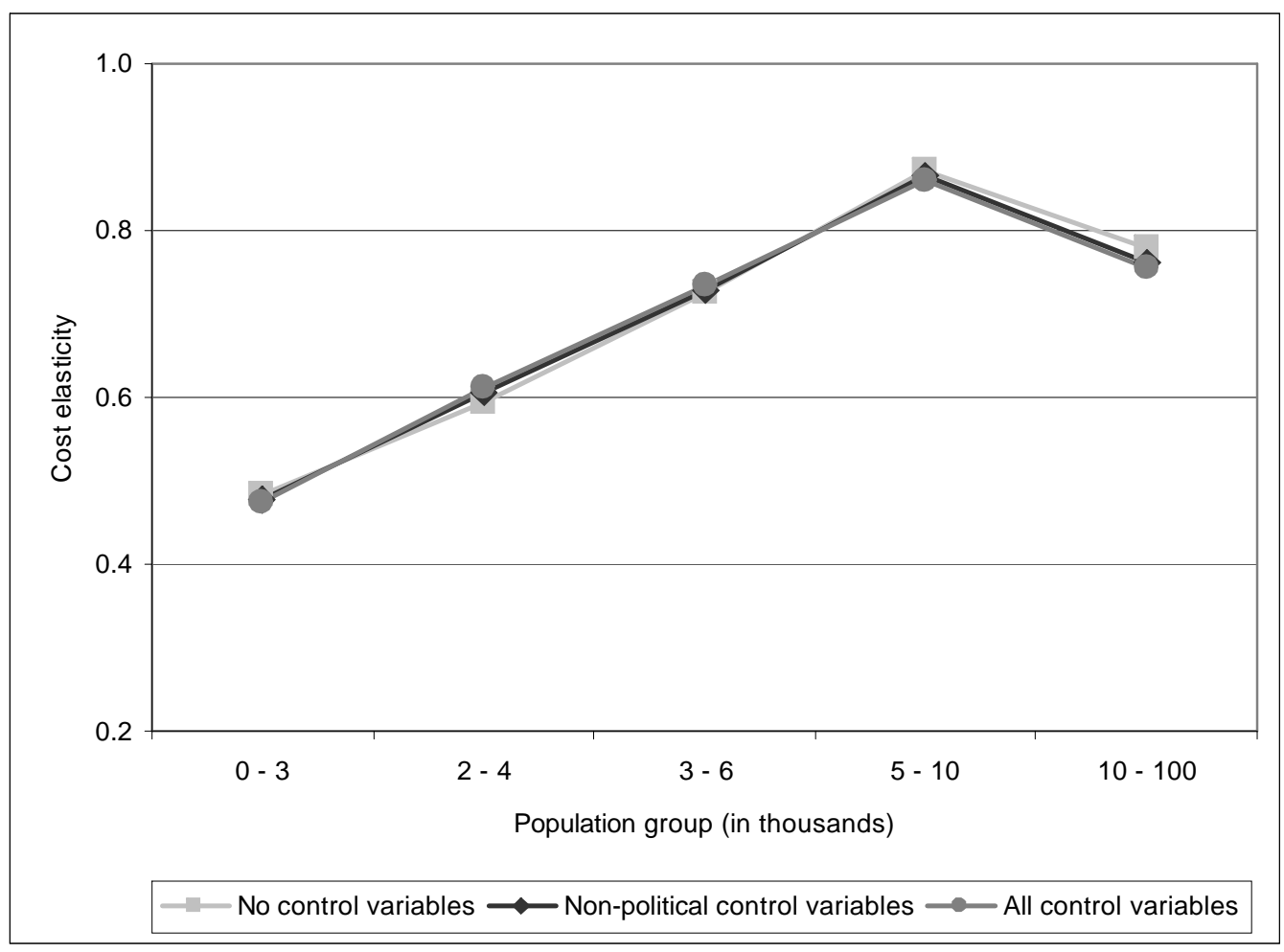

Note: Results based on Cobb-Douglas cost function.

Figure 3 illustrates that, for the main part of the range in population size in our sample, cost elasticity is an increasing function of population size (whether or not the control variables are included). That is, these elasticities appear (much) stronger for smaller municipalities than for larger ones. Indeed, for the smallest municipalities, the results hint towards substantial economies of scale in the sense that a one percentage increase in total population only leads to an increase in costs of approximately $0.5 \%$. Nevertheless, economies of scale become (close to) exhausted once population size reaches approximately 10.000 inhabitants. Therefore, cost pressure as a result of a shrinking population threatens particularly municipalities in the size class up to approximately 10.000 inhabitants. An important (policy) implication of this analysis is therefore that smaller municipalities might be more extensively confronted with the question of mergers - or inter-municipal cooperation in the provision of at least certain 
types of public goods - once the demographic change gains momentum (compared to larger municipalities). ${ }^{15}$

\section{Conclusion}

Demographic change constitutes a major challenge for local public finances in Germany. Our results underscore the importance of taking this demographic shock seriously. Our first major finding in this context is the substantial heterogeneity in the efficiency of public service production - even under a uniform institutional setting as it is given for the municipalities in Baden-Württemberg. We show, that, on average, the municipalities of Baden-Württemberg produce their output with costs roughly $12 \%$ to $14 \%$ above the efficient frontier as identified by means of a stochastic frontier analysis - even when taking account of different socioeconomic and political constraints. At first sight, this unexploited potential might appear as a cushion for bad times once population shrinkage materializes. The more pessimistic interpretation, however, is to take these inefficiencies as an indicator of poor performance generally, and with respect to adverse economic and fiscal developments in particular. Following this view, municipalities which are characterized by low efficiency scores under the current demographic situation are likely to incur significant difficulties in the future, when demographic decline gains force. One can indeed expect that inefficiencies augment when these low performing municipalities are faced with the challenge to adjust their public services to the needs of a changing and shrinking population.

Our second major finding relates to the properties of the cost function of public service production. In fact, costs are found to fall underproportionally with a shrinking population in small municipalities (with up to approximately 10.000 inhabitants). This substantiates the concern that the upcoming decrease of population will raise per capita costs of public service production for this size class of municipalities. This insight suggests that population shrinkage predominantly poses cost pressure problems for smaller units and could - or should - bring the debate on mergers or more intensive co-operation among smaller entities back on the agenda.

15 Clearly, we analyze the 'optimal' (population) size of municipalities with respect to cost considerations only. This disregards other characteristics that may play a role here (such as geographical characteristics). 


\section{References}

Ashworth, J., B. Geys. B. Heyndels, and F. Wille (2006). Political Competition and Local Government Performance: Evidence from Flemish Municipalities, paper presented at the annual EPCS Meeting, April 2006, Turku (Finland).

Athanassopoulos, A., and K. Triantis (1998). Assessing aggregated cost efficiency and the related policy implications for Greek local municipalities. Infor, 36: 66-83

Aigner, D.J., C.A.K. Lovell, and P. Schmidt (1977). Formulation and estimation of stochastic frontier production function models. Journal of Econometrics, 6: 21-37.

Balaguer-Coll, M.T., D. Prior, and E. Tortosa-Ausina (2007). On the determinants of local government performance: A two-stage nonparametric approach. European Economic Review, 51(2): 425-451.

Batini, N., T. Callen, and W. McKibbin (2006). The Global Impact of Demographic Change. IMF Working Paper, No. WP/06/9.

Battese G.E., and T.J. Coelli (1995). A Model for Technical Efficiency Effects in a Stochastic Frontier Production Function with Panel Data. Empirical Economics, 20: 325-332.

Bauer, P.W. (1983). A technique for estimating a cost system that allows for inefficiency. Federal Reserve Bank of Cleveland Working Paper, No. 8704.

Bloom, D.E., and D. Canning (2004). Global Demographic Change: Dimensions and Economic Significance. NBER Working Paper, No. 10817.

Borge, L.-E., T. Falch, and P. Tovmo (2007). Public Sector Efficiency: The Impact of Political and Budgetary Institutions, Fiscal Capacity and Democratic Participation. NTNU Department of Economics Working Paper, No. 2007/01.

Christensen, L.R., D.W. Jorgenson, and L.J. Lawrence (1973). Transcendental logarithmic production frontiers. Review of Economics and Statistics, 55(1): 28-45.

Coelli T.J. (1996). A Guide to FRONTIER version 4.1: A Computer Program for Stochastic Frontier Production and Cost Function Estimation. CEPA Working papers, No. 7/96.

De Borger, B., K. Kerstens, W. Moesen, and J. Vanneste (1994). Explaining differences in productive efficiency: An application to Belgian municipalities. Public Choice, 80: 339358.

De Borger, B., and K. Kerstens (1996). Cost efficiency of Belgian local governments: A comparative analysis of FDH, DEA and econometric approaches. Regional Science and Urban Economics, 26: 145-170.

De Borger, B., and K. Kerstens (2000). What is known about municipal efficiency? The Belgian case and beyond. In: Public Provision and Performance: Contributions from Efficiency and Productivity Measurement, ed. J. Blank, 299-330. Elsevier: Amsterdam.

De Prins, D., L. Simar, and H. Tulkens (1984). Measuring labour efficiency in post offices. In: The Performance of Public Enterprises: Concepts and Measurement, eds. M. Marchand, P. Pestieau and H. Tulkens, 243-267. Amsterdam: North Holland.

Eurostat (2006). Population Statistics, Luxemburg.

Farrell, M. (1957). The measurement of productive efficiency. Journal of the Royal Statistical Society, Series A: General 120: 253-281. 
Federal Statistical Office Germany (2006a). Bevölkerung im Jahr 2005 leicht gesunken. Wiesbaden.

Federal Statistical Office Germany (2006b). Bevölkerung Deutschlands bis 2050 - 11 . koordinierte Bevölkerungsvorausberechnung. Wiesbaden.

Felmingham, B., N.O. Jackson, and Q. Zhang (2002). Indicative Impacts of Population Decline on the Operations of Local Government in Tasmania. Australasian Journal of Regional Studies, 8(1): 95-109.

Gern, A. (2005). Kommunalrecht Baden-Württemberg. Nomos, Baden-Baden, 117-129.

Geys, B. (2006). Looking across borders: A test of spatial policy interdependence using local government efficiency ratings. Journal of Urban Economics, 60 (3): 443-462.

Geys B., and W. Moesen (2007a). Measuring Local Government Technical Efficiency in Flemish Municipalities: An Application and Comparison of FDH, DEA and Econometric Approaches. WZB Berlin, mimeo.

Geys B., and W. Moesen (2007b). Sources of Local Government Technical Efficiency: Evidence from Flemish Municipalities. WZB Berlin, mimeo.

Hayes, K., and S. Chang (1990). The relative efficiency of city manager and mayor-council forms of government. Southern Economic Journal, 57: 167-177.

Heilbrun, J. (1992). Art and Culture as Central Place Functions. Urban Studies, 29 (2): 205215.

Hindriks, J., and F. Gerard (2005). Le palmares des villes et communes en Wallonie: Une approche en termes d'efficacité. Regards Économiques, 35: 1-16.

Jackson, N.O., and B. Felmingham (2002). As the Population Clock winds down: Indicative Effects of Population Ageing in Australia's States and Territories. Journal of Population Research, 19(2): 97-118.

Jackson, N.O. (2004). Some Considerations on Regional Population Ageing and Local Government Funding in Australia. University of Tasmania, mimeo.

Jondrow, J., C.A.K. Lovell, I. Materov, and P. Schmidt (1982). On the estimation of technical inefficiency in the stochastic frontier production function model. Journal of Econometrics, 19: $233-238$.

Kalseth, J., and J. Ratts $\varnothing$ (1998). Political control of administrative spending: The case of local governments in Norway. Economics and Politics, 10: 63-83.

Lovell, C.A.K. (1993). Production frontiers and productive efficiency. In: The Measurement of Productive Efficiency: Techniques and Applications, eds. H. Fried, C.A.K. Lovell and S. Schmidt, 3-67. Oxford: Oxford University Press.

Meeusen, W., and J. van den Broeck (1977). Efficiency estimation from Cobb-Douglas production functions with composed error. International Economic Review, 18 (2): 435444.

Méon, P.-G., and L. Weill (2005). Does better governance foster efficiency? An aggregate frontier analysis. Economics of Governance, 6(1): 75-90.

Samapio De Sousa, M.C., and B. Stosic (2005). Technical efficiency of the Brazilian municipalities: Correcting non-parametric frontier measurements for outliers. Journal of Productivity Analysis, 24: 157-181. 
Seitz, H., D. Freigang, S. Högel, and G. Kempkes (2007). Die Auswirkungen der demographischen Veränderungen auf die Budgetstrukturen der öffentlichen Haushalte. Perspektiven der Wirtschaftspolitik, 8(2): 147-164.

Stevens P.A. (2004). Accounting for Background Variables in Stochastic Frontier Analysis. NIESR Discussion Paper, No. 239.

Stevens P.A. (2005). Assessing the Performance of Local Government. National Institute Economic Review, No. 193.

Van de Kaa, D.J. (1987). Europe's Second Demographic Transition. Population Bulletin, 42(1), Population Reference Bureau, Washington, D.C.

Vanden Eeckhaut, P., H. Tulkens, and M. Jamar (1993). Cost efficiency in Belgian municipalities. In: The Measurement of Productive Efficiency: Techniques and Applications, eds. H. Fried, C.A.K. Lovell and S. Schmidt, 300-334. Oxford: Oxford University Press.

Worthington, A.C. (2000). Cost efficiency in Australian local government: A comparative analysis of mathematical programming and econometric approaches. Financial Accoutability and Management, 16 (3): 201-223. 


\section{Appendix A}

Table A1: Results of the multi-output frontier estimation

\begin{tabular}{|c|c|c|c|c|c|c|}
\hline \multirow{2}{*}{ Variable } & \multicolumn{3}{|c|}{ Cobb-Douglas } & \multicolumn{3}{|c|}{ Translog } \\
\hline & (1) & (2) & (3) & (4) & (5) & (6) \\
\hline constant $\left(\beta_{0}\right)$ & $\begin{array}{c}8.303 * * * \\
(55.864)\end{array}$ & $\begin{array}{c}8.590 * * * \\
(58.270)\end{array}$ & $\begin{array}{l}8.516^{* * * *} \\
(60.753)\end{array}$ & $\begin{array}{l}11.455 * * * \\
(7.946)\end{array}$ & $\begin{array}{l}11.627 * * * \\
(6.695)\end{array}$ & $\begin{array}{l}12.953 * * * \\
(4.250)\end{array}$ \\
\hline $\begin{array}{l}\text { A: students in public } \\
\text { schools }\end{array}$ & $\begin{array}{l}-0.008 \\
(-0.924)\end{array}$ & $\begin{array}{l}-0.009 \\
(-0.953)\end{array}$ & $\begin{array}{l}-0.002 \\
(-0.202)\end{array}$ & $\begin{array}{c}0.096 \\
(0.485)\end{array}$ & $\begin{array}{c}0.017 \\
(0.094)\end{array}$ & $\begin{array}{c}0.051 \\
(0.255)\end{array}$ \\
\hline $\begin{array}{l}\text { B: kindergarten } \\
\text { places }\end{array}$ & $\begin{array}{l}0.059 * \\
(1.903)\end{array}$ & $\begin{array}{l}0.077 * * * \\
(2.661)\end{array}$ & $\begin{array}{l}0.069 * * \\
(2.411)\end{array}$ & $\begin{array}{l}-0.066 \\
(-0.116)\end{array}$ & $\begin{array}{l}-0.050 \\
(-0.099)\end{array}$ & $\begin{array}{c}0.181 \\
(0.194)\end{array}$ \\
\hline $\mathrm{C}$ : recovery area & $\begin{array}{l}0.019 * * \\
(2.214)\end{array}$ & $\begin{array}{l}0.020^{* *} \\
(2.448)\end{array}$ & $\begin{array}{l}0.018 * * \\
(2.158)\end{array}$ & $\begin{array}{c}0.623 * * * \\
(2.709)\end{array}$ & $\begin{array}{l}0.583 * * * \\
(2.674)\end{array}$ & $\begin{array}{l}0.552^{* *} \\
(2.420)\end{array}$ \\
\hline D: total population & $\begin{array}{c}0.680 * * * \\
(12.066)\end{array}$ & $\begin{array}{c}0.631 * * * \\
(11.737)\end{array}$ & $\begin{array}{l}0.641 * * * \\
(12.000)\end{array}$ & $\begin{array}{c}-0.999 \\
(-0.957)\end{array}$ & $\begin{array}{c}-0.922 \\
(-0.658)\end{array}$ & $\begin{array}{l}-2.161 \\
(-0.936)\end{array}$ \\
\hline $\begin{array}{l}\text { E: population older } \\
\text { than } 65\end{array}$ & $\begin{array}{c}0.140 * * * \\
(3.682)\end{array}$ & $\begin{array}{c}0.151 * * * \\
(4.211)\end{array}$ & $\begin{array}{c}0.157 * * * \\
(4.367)\end{array}$ & $\begin{array}{c}-0.022 \\
(-0.024)\end{array}$ & $\begin{array}{l}-0.099 \\
(-0.095) \\
\end{array}$ & $\begin{array}{c}0.904 \\
(0.660) \\
\end{array}$ \\
\hline $\begin{array}{l}\text { F: number of social } \\
\text { insured employees }\end{array}$ & $\begin{array}{c}0.133 * * * \\
(10.960)\end{array}$ & $\begin{array}{c}0.137 * * * \\
(11.798)\end{array}$ & $\begin{array}{c}0.133 * * * \\
(12.381)\end{array}$ & $\begin{array}{c}0.862 * * * \\
(2.885)\end{array}$ & $\begin{array}{c}0.908 * * * \\
(3.475)\end{array}$ & $\begin{array}{c}0.908 * * * \\
(3.203)\end{array}$ \\
\hline $\mathrm{A}^{2}$ & & & & $\begin{array}{c}-0.004 \\
(-0.517)\end{array}$ & $\begin{array}{c}-0.002 \\
(-0.235)\end{array}$ & $\begin{array}{c}-0.002 \\
(-0.209) \\
\end{array}$ \\
\hline $\mathrm{B}^{2}$ & & & & $\begin{array}{c}0.021 \\
(0.487)\end{array}$ & $\begin{array}{c}0.025 \\
(0.596)\end{array}$ & $\begin{array}{c}0.025 \\
(0.554)\end{array}$ \\
\hline $\mathrm{C}^{2}$ & & & & $\begin{array}{c}0.000 \\
(0.039)\end{array}$ & $\begin{array}{c}0.002 \\
(0.231)\end{array}$ & $\begin{array}{c}0.002 \\
(0.331)\end{array}$ \\
\hline $\mathrm{D}^{2}$ & & & & $\begin{array}{c}0.221 \\
(0.946)\end{array}$ & $\begin{array}{c}0.189 \\
(0.634)\end{array}$ & $\begin{array}{c}0.445 \\
(0.997)\end{array}$ \\
\hline $\mathrm{E}^{2}$ & & & & $\begin{array}{l}-0.008 \\
(-0.047)\end{array}$ & $\begin{array}{l}-0.036 \\
(-0.227)\end{array}$ & $\begin{array}{c}0.071 \\
(0.408)\end{array}$ \\
\hline $\mathrm{F}^{2}$ & & & & $\begin{array}{c}0.101 * * * \\
(6.797)\end{array}$ & $\begin{array}{c}0.091 * * * \\
(6.289)\end{array}$ & $\begin{array}{c}0.091 * * * \\
(6.219)\end{array}$ \\
\hline $\mathrm{F} * \mathrm{E}$ & & & & $\begin{array}{c}-0.048 \\
(-0.656)\end{array}$ & $\begin{array}{c}-0.025 \\
(-0.366)\end{array}$ & $\begin{array}{c}-0.007 \\
(-0.104)\end{array}$ \\
\hline $\mathrm{F} * \mathrm{D}$ & & & & $\begin{array}{c}-0.327 * * * \\
(-2.902)\end{array}$ & $\begin{array}{c}-0.331 * * * \\
(-3.329)\end{array}$ & $\begin{array}{c}-0.340 * * * \\
(-3.175)\end{array}$ \\
\hline $\mathrm{F} * \mathrm{C}$ & & & & $\begin{array}{c}0.022 \\
(1.433)\end{array}$ & $\begin{array}{c}0.017 \\
(1.177)\end{array}$ & $\begin{array}{c}0.021 \\
(1.412)\end{array}$ \\
\hline $\mathrm{F} * \mathrm{~B}$ & & & & $\begin{array}{c}0.153 * * \\
(2.456)\end{array}$ & $\begin{array}{c}0.152 * * * \\
(2.830)\end{array}$ & $\begin{array}{c}0.145^{* *} \\
(2.436)\end{array}$ \\
\hline $\mathrm{F} * \mathrm{~A}$ & & & & $\begin{array}{c}0.003 \\
(0.227)\end{array}$ & $\begin{array}{c}0.005 \\
(0.328)\end{array}$ & $\begin{array}{c}0.003 \\
(0.195)\end{array}$ \\
\hline $\mathrm{E} * \mathrm{D}$ & & & & $\begin{array}{c}0.159 \\
(0.381) \\
\end{array}$ & $\begin{array}{c}0.192 \\
(0.444)\end{array}$ & $\begin{array}{c}-0.182 \\
(-0.336)\end{array}$ \\
\hline $\mathrm{E} * \mathrm{C}$ & & & & $\begin{array}{l}0.104 * \\
(1.765)\end{array}$ & $\begin{array}{l}0.102^{*} \\
(1.818)\end{array}$ & $\begin{array}{c}0.090 \\
(1.584)\end{array}$ \\
\hline $\mathrm{E} * \mathrm{~B}$ & & & & $\begin{array}{c}-0.315 \\
(-1.537)\end{array}$ & $\begin{array}{c}-0.286 \\
(-1.374)\end{array}$ & $\begin{array}{c}-0.149 \\
(-0.582)\end{array}$ \\
\hline $\mathrm{E} * \mathrm{~A}$ & & & & $\begin{array}{c}0.033 \\
(0.538)\end{array}$ & $\begin{array}{c}0.008 \\
(0.139)\end{array}$ & $\begin{array}{c}0.010 \\
(0.154)\end{array}$ \\
\hline $\mathrm{D} * \mathrm{C}$ & & & & $\begin{array}{c}-0.178 * * \\
(-2.023)\end{array}$ & $\begin{array}{c}-0.171 * * \\
(-2.048)\end{array}$ & $\begin{array}{l}-0.157^{*} \\
(-1.811)\end{array}$ \\
\hline $\mathrm{D} * \mathrm{~B}$ & & & & $\begin{array}{c}0.108 \\
(0.513)\end{array}$ & $\begin{array}{c}0.101 \\
(0.455)\end{array}$ & $\begin{array}{c}-0.021 \\
(-0.061)\end{array}$ \\
\hline $\mathrm{D} * \mathrm{~A}$ & & & & $\begin{array}{c}-0.041 \\
(-0.475)\end{array}$ & $\begin{array}{c}0.004 \\
(0.046) \\
\end{array}$ & $\begin{array}{c}-0.002 \\
(-0.025)\end{array}$ \\
\hline$C * B$ & & & & $\begin{array}{c}0.004 \\
(0.084)\end{array}$ & $\begin{array}{c}0.006 \\
(0.133)\end{array}$ & $\begin{array}{c}-0.004 \\
(-0.076)\end{array}$ \\
\hline $\mathrm{C} * \mathrm{~A}$ & & & & 0.008 & 0.006 & 0.008 \\
\hline
\end{tabular}




\begin{tabular}{|c|c|c|c|c|c|}
\hline & & & $(0.672)$ & $(0.529)$ & $(0.692)$ \\
\hline $\mathrm{B} * \mathrm{~A}$ & & & $\begin{array}{l}-0.001 \\
(-0.12)\end{array}$ & $\begin{array}{c}-0.032 \\
(-0.574)\end{array}$ & $\begin{array}{c}-0.031 \\
(-0.484)\end{array}$ \\
\hline constant $\left(\delta_{0}\right)$ & $\begin{array}{l}-7.394 * \\
(-1.780)\end{array}$ & $\begin{array}{l}-7.539 * * * \\
(-21.180)\end{array}$ & & $\begin{array}{l}-6.356 * * \\
(-2.496)\end{array}$ & $\begin{array}{l}-7.038^{*} \\
(-1.913)\end{array}$ \\
\hline $\begin{array}{l}\text { unemployed as share } \\
\text { of population }\end{array}$ & $\begin{array}{c}0.085 \\
(0.684)\end{array}$ & $\begin{array}{c}0.224 * * * \\
(5.355)\end{array}$ & & $\begin{array}{l}-0.138 * * \\
(-2.453)\end{array}$ & $\begin{array}{c}0.111 \\
(1.360)\end{array}$ \\
\hline population density & $\begin{array}{l}0.219 * * \\
(2.070)\end{array}$ & $\begin{array}{c}0.202 * * * \\
(21.069)\end{array}$ & & $\begin{array}{l}0.063 * * \\
(2.405)\end{array}$ & $\begin{array}{l}0.099 * \\
(1.884)\end{array}$ \\
\hline Herfindahl index & & $\begin{array}{c}3.606^{* * *} * \\
(21.906) \\
\end{array}$ & & & $\begin{array}{c}2.768 * * \\
(1.974)\end{array}$ \\
\hline $\begin{array}{l}\text { Cobb-Douglas vs. } \\
\text { translogarithmic }\end{array}$ & & & $125.376 * * *$ & $111.565^{* * *}$ & $106.867 * * *$ \\
\hline
\end{tabular}

Note: $\mathrm{N}=1021$; All variables in natural logs except the socio-economic and political variables; $* * *$ denotes significance at $1 \%$ level, $* *$ at $5 \%$ level and * at $10 \%$ level. Cobb-Douglas vs. translogarithmic tests the restriction that the coefficients for all quadratic and cross products terms are jointly insignificant. Both tests have a $\mathrm{Chi}^{2}$-distribution.

Table A2: Summary statistics of the input, output and environmental variables for the 1021 municipalities of Baden-Württemberg in 2001

\begin{tabular}{l|c|c|c|c}
\hline & Mean & $\begin{array}{c}\text { Standard } \\
\text { deviation }\end{array}$ & Minimum & Maximum \\
\hline $\begin{array}{l}\text { Current primary expenditures (in } \\
\text { mio. euros) }\end{array}$ & 37.9 & 134.0 & 0.7 & 3230.0 \\
\hline Students in public schools & 649.9 & 1292.8 & 0.0 & 26342.0 \\
Kindergarten places & 402.1 & 804.7 & 25.0 & 17195.0 \\
Recovery area (in are) & 2401.5 & 5787.8 & 5.0 & 107540.0 \\
Total population & 10369.7 & 26594.7 & 249.0 & 589037.0 \\
Population older than 65 & 1668.9 & 4481.3 & 35.0 & 98205.0 \\
$\begin{array}{l}\text { Number of social insured } \\
\text { employees (at place of work) }\end{array}$ & 3753.2 & 14919.1 & 8.0 & 353801.0 \\
\hline Unemployed as a share of total & 1.9 & 0.6 & 0.3 & 4.7 \\
population (in \%) & 3.3 & 3.3 & 0.2 & 28.4 \\
Population density (inhabitants & 0.5 & 0.3 & 0.2 & 1.0 \\
per are) & Herfindahl index & & & \\
\hline
\end{tabular}

Source: Statistical office of Baden-Württemberg 